\title{
エジプト初期王朝時代の石製容器副葬の階層構造と社会的機能 \\ Hierarchical Structure and Social Function in Mortuary Consumption of Stone Vessels in Early Dynastic Egypt
}

竹野内 恵 太 TAKENOUCHI Keita

\begin{abstract}
In Early Dynastic Egypt, stone vessels were manufactured on a large scale, probably by fulltime specialists attached to the government or palace. The stone vessel was established as the primary piece of burial equipment during this period. Scholarship has focused on aspects of stone vessel production such as 'large-scale production' and 'attached specialisation'. However, the mortuary use of stone vessels has not been analysed in depth. Therefore, this paper clarifies the structure of their mortuary use and the background of their large-scale production, by comparing the assemblages of stone vessels found in tombs with the social class of the deceased.

It was found that in the First Dynasty, the tombs of the higher classes in the Memphite region contained a variety of wares, including specialty wares and vessels of stone such as mudstone, basalt, and tuff from remote quarries. But in the Second Dynasty, the geographical distribution of stone vessels expanded. In parallel with that, the hierarchical ranking of stone vessels appeared also in local sites. It is argued that during the Second Dynasty the mortuary consumption of stone vessels was widely promoted in the whole Nile Valley by the royal court and that, kings and high officials distributed stone vessels to powerful local clans in order to create bonds between the center and local areas. At any rate, stone vessels were the preferred political and symbolic resource for promoting regional integration throughout the Early Dynastic society of Egypt.
\end{abstract}

\section{I. はじめに一問題提起と研究目的一}

エジプトでは，初期王朝時代（c. 3050 2650 BC）に入ると支配権力の広域的な浸透と政治的な地域 統合に伴って，物質文化は各地で斉一性を帯びる。大型墓のプランは共通する構造になり，副葬土器は 日常利用の土器が全土で等しく選択された（Engel 2013; Hendrickx 2014）。ケンプは，初期国家成立期 である当該期の物質文化を「支配者層が選択し，洗練した選好のセット」と表現している（Kemp 2000， 237)。このような「選好セット」の中でまず想起する器物に石製容器が挙げられる。

石製容器は, 岩石の美麗な色調・葉理に加え, 素材獲得および容器状に加工する作業量の多さから, 極めて高価な副葬品であったことが窅われる。初期王朝時代の支配者層が埋葬された北サッカラとウン ム・エル＝カアブの墓地には膨大な石製容器が副葬され，この時期に石製容器生産は古代エジプト史を 通じて最興隆期を迎える。誇示的消費とも解釈できるような現象が早くから認識され，それゆえ石製容 器の生産・流通は当時の支配権力下で管理統制されていたと考えられている。また，石製容器が副葬さ れた墓は，大量生産化を迎える初期王朝時代でもある程度限定的であった。石製容器を副葬できた被葬 者は生前経済的に豊かで, 社会的地位の高い人物であったことは想像に難くない。

* 早稲田大学文学学術院助手

Research Associate, Faculty of Letters, Arts and Sciences, Waseda University

(C) 2017 The Society for Near Eastern Studies in Japan 


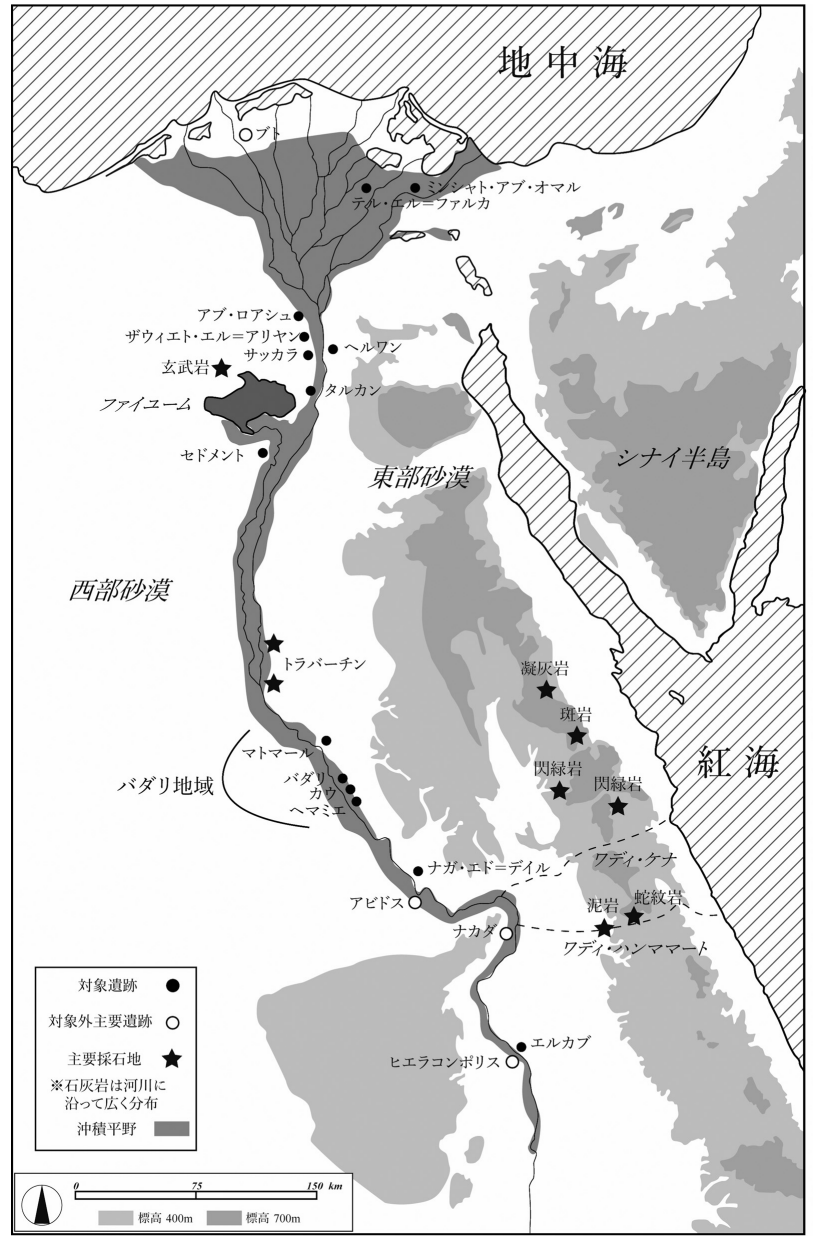

図 1 エジプト全図
当該期の石製容器の研究では, 器形分 類や編年研究（Emery 1949; Klasens 1958; 1959; 1960; 1961; Kouli 1978; Hendrickx 1994; Kopp 2007), 産地同定 (Aston 1994; Harrel et al. 2000; Mallory 2000; Bloxam et al. 2014）などの基礎研 究を経て, 近年では工房址出土の製作道 具や博物館資料の遺物観察によって製作 技法の復元に目が向き始め, より具体的 な生産メカニズムを解明しようとする動 きがある（Schmidt 1988; Jórdeczka 2004； Hendrickx et al. 2011; 竹野内 2015; 2016)。ただし，大量生産化という現象 は得てして専業化など供給面での重要性 ばかり取り上げられる（Hendrickx 2011）。 初期国家の成立期において大量副葬され るという特異な現象の背景について具体 的な議論はない。石製容器の増加は上位 層において経済的機会が増加したことを 示すとしばしば説明されるが，石製容器 自体の社会的機能・意味といった需要面 の具体像を積極的に評価しょうとする機 運にはないのである。器物の需要はまさ に生産における動機であり, 需要面を明

らかにすれば，大量生産化の背景やそれを必要とした当時の社会状況をより深く考察することができる。 石製容器は基本的に副葬品であるため, 需要とは副葬品としての社会的機能・意味に対するものと捉 えることが可能であろう。こうした機能・意味を理解するためには, 副葬状況を考察し, 副葬の原理や 構造を明らかにするのが不可欠である。そこで副葬状況を分析するに当たって, 石製容器と共変動する, あるいは比較できる墓の属性を設定する。石製容器は先述した通り, 富裕墓に副葬される経済的価値の 高い器物である。一方で, その器種組成や石材構成は各墓でバラつきがあることから, より具体的な副 葬状況を考える必要がある。よって, 石製容器の需要面を研究する端緒として, 本稿ではまず被葬者の 階層性と器種組成および石材構成のアセンブリッジの相関関係を分析する。

本稿では, 主として石製容器副葬に見られる階層性を器種構成と石材構成から地域および時期ごと （第 $1 ・ 2$ 王朝）に分析し，石製容器が大量副葬された背景について考察することを目的とする。まず,

（1）初期王朝時代において石製容器は副葬品の約20\%を占めるようになる（Hendrickx 2011, 95)。また，エリス (Ellis) によるタルカンでの統計分析では，石製容器を副葬する墓は概して大型墓に密集するとしている（Ellis 1992)。さらに，コップによれば，第 1 王朝時代になると各墓間の石製容器副葬点数の開きが大きくなることから, 石製容器の富裕層への集中が顕現するという（Kopp 2007）。 
石製容器を副葬した被葬者の社会的格差の設定や器形・器種分類, 前提条件を明示する。次に, 社会階 層と石製容器の多様な器種や石材の相関性を分析し, どの位層の被葬者がどのような器種組成・石材構 成の石製容器を保有するのかを明らかにする。また, 分析に移る前に, 当時の支配者層の集団が埋葬さ れた北サッカラ台地東縁部の大型マスタバ墓群とアビドスのウンム・エル＝カアブ墓地出土の石製容器 を概観し，その卓越性と特異性を確認することで，続く分析の比較材料とする。最後に，分析結果を受 けて, なぜ石製容器が当該期に大量生産されたのか, 初期王朝時代の社会状況におけるその社会的価值・ 機能といった需要面を浮き彫りにしたい。

\section{II. 分析方法}

被葬者の社会的格差を相対化するにあたって, 埋葬施設に費やされた労力（effort or energy expenditure）に着目し, 石製容器組成との共変動を分析する指標を設ける。これは, 墓壙面積や体積, 構造, 形態, 副葬品の点数と種類数が墓地を組織する共同体内の階層秩序を反映するという考古学的仮定と民 族誌的類推に基づく（Binford 1971; Tainter 1978; Brown 1981; O’Shea 1984; Carr 1995）。

既往の先・初期王朝時代の墓制や社会的格差に関する研究では, 墓壙面積や体積, 構造を指標として 社会階層を設定してきた（Bard 1988; Griswold 1992; Wetering 2003; Köhler 2008; 張替 1991）。初期 王朝時代は社会階層の分化が著しいため, 墓構造や副葬品の多葟から明確なピラミッド型の社会形態を 構成するとされる（Köhler 2008, 384）。本稿でも墓構造の複雑性を指標として被葬者の社会的格差を相 対化する。各階層の集団が保有する器種や石材, 副葬点数をパターン化することで, 石製容器の副葬構 造と原理について一考できる。

\section{1. 墓構造の分類亡階層秩序の設定}

本稿では初期王朝時代の墓を土壙墓，堅穴式墓，地下式横穴墓，マスタバ墓の 4 類に大別する（図 2 ）。 概ねこの順序にしたがって墓壙の掘削や建造に投下される労力は多くなる。さらに，棟瓦壁・埋葬室に 続く戸口・木製天井張り・壁弇（副葬品収納スペース）の有無, 部屋の数によって先の 4 類を細別し, 墓建造にかかった労働投下量を基準として墓構造を類型化し，墓壙間で相対化する。また，墓構造の複 雑性と墓壙規模の大小はどの遺跡でも概社相関している一方で, アブ・ロアシュやナガ・エド＝デイル については, 同じ墓構造であるものの明らかに規模が大きなものも一部存在する。その場合は, 墓構造 の類型つまり階層を一つ繰り上げる形で補完した。その逆むまた同じである。対象とする遺跡は, 発掘 報告書に墓構造と規模が掲載されていて且つ副葬された石製容器の器形および使用石材を明記している 遺跡を選定した（図 1)。そして，墓構造は全遺跡で一様ではないため，それぞれ遺跡ごとに墓構造を 類型化し, 被葬者の階層秩序を設定した（表 1 ）。なお, ミンシャト・アブ・オマルについては, 全て 土壙墓であるため, 墓壙規模から便宜的に設定した。各墓の帰属時期はヘンドリックスによる土器編年 に依拠しているが（Hendrickx 1996），セドメントおよびナガ・エド＝デイルについては報告書の記載 に従った。また, バダリとカウ, ヘマミエ, マトマールは一括してバダリ地域として扱う。

（2）ここで言う規模は墓壙面積のことで，墓壙の長軸と短軸の積である。しかし，全ての墓が矩形ではないため， 正確には規模の指数である。 


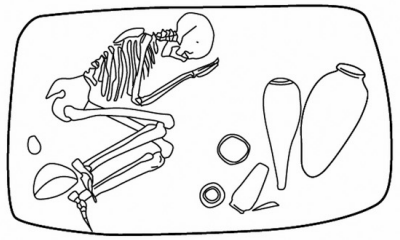

土壙墓

(エルカブ遺跡 18 号墓)

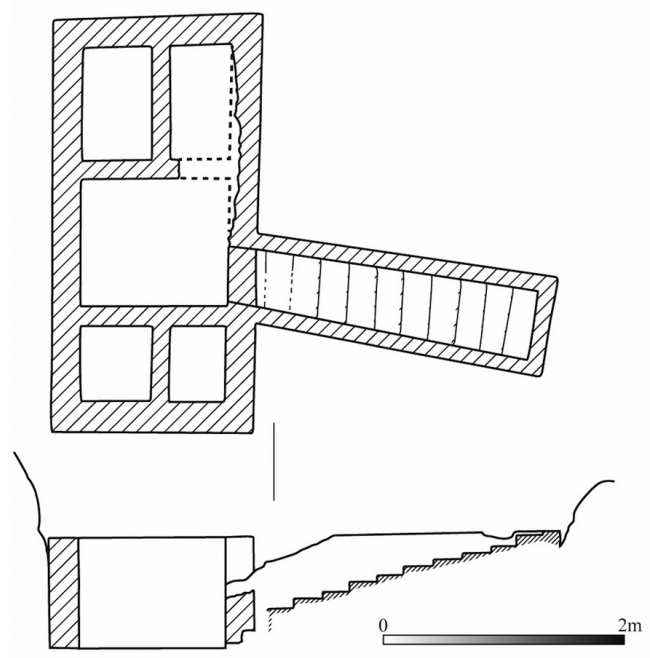

地下式横穴墓（複室構造）

(ナガ・エド=デイル遗跡 N1512 号墓)


㹂穴式煉瓦壁墓

(ナガ・エド=デイル遺跡 N1501 号墓)
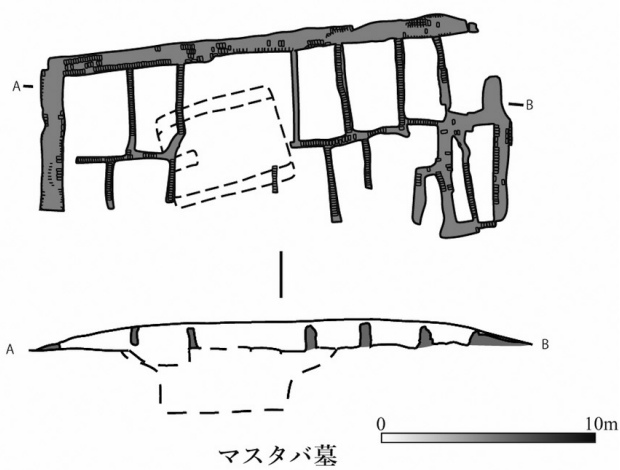

(ヘルワン遺䟢 $4 / 1$ 号墓)

図 2 初期王朝時代の墓構造（Reisner 1908, figs. 24, 25, 68, 70; Hendrickx 1994, pl. 37; Köhler 2013, figs. 6,10 を元に作成)

表 1 本稿で扱う各遺跡の墓構造分類

\begin{tabular}{|c|c|c|c|c|c|c|c|c|c|}
\hline \multicolumn{10}{|c|}{ 東部デル夕地域 } \\
\hline 遗跡 & 類型 & 募櫣造 & 借考 & 出典 & 遺跡 & 類型 & \%募構造 & 備考 & 出典 \\
\hline \multirow{3}{*}{$\begin{array}{l}\text { テル・エル }= \\
\text { ファルカ }\end{array}$} & Class I & 土荟墓 & 矩形 & \multirow{3}{*}{$\begin{array}{l}\text { Chłodnicki et al. } \\
\qquad 2012\end{array}$} & \multirow{3}{*}{$\begin{array}{l}\text { ミンシャト. } \\
\text { アプ・オマル }\end{array}$} & Class I & 墓榐規模100以下 & \multirow{3}{*}{$\begin{array}{l}\text { 棈円形あるいは } \\
\text { 矩形の土壃墓 }\end{array}$} & \multirow{3}{*}{$\begin{array}{l}\text { Kroeper and Wildung } \\
1994 ; 2000\end{array}$} \\
\hline & Class II & 竪穴式煤瓦壁墓 & 単室構造 & & & Class II & 募境規模101 200 & & \\
\hline & Class III & 堅穴式煉瓦壁墓 & 複空構造 & & & Class III & 墓境规模201 300 & & \\
\hline \multicolumn{10}{|c|}{ メンフィス地域 } \\
\hline 遺跡 & 類型 & 墓構造 & 借考 & 出典 & 遗跡 & 類型 & 墓構造 & 備考 & 出典 \\
\hline \multirow{4}{*}{ アプ・ロアシニ } & Class I & 土塨墓 & 棈円形あるいは矩形 & \multirow{4}{*}{$\begin{array}{l}\text { Klasens 1958; } \\
\text { 1959; 1960; } 1961\end{array}$} & \multirow{3}{*}{$\begin{array}{l}\text { ザウイエト． } \\
\text { エルンアリヤン }\end{array}$} & Class I & 土墴墓 & 棈円形あるいは矩形 & \multirow{3}{*}{ Dunham 1978} \\
\hline & Class II & 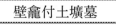 & 矩形で容器を埋納する壁萻をもつ & & & Class II & 竪穴式娻瓦壁墓 & 単窒構造 & \\
\hline & Class III & 地下式横穴墓 & 単室・複室でも規模指数が149以下のもの & & & Class III & 堅穴式煉瓦壁墓 & 単室, 木製天井張り & \\
\hline & Class IV & 地下式横穴蓦 & 複室・単室でも規模指数が150以上のもの & & - & & & & \\
\hline \multirow{5}{*}{ ヘルワン } & Class I & 土媛墓 & 円形あるいは矩形 & \multirow{5}{*}{ Köhler 2014} & & & & & \\
\hline & Class II & 両袖栩付土喏募 & 矩形で長軸側面にステッブが作出された土墌墓 & & & & & & \\
\hline & Class III & 地下式横穴墓 & 単室構造 & & & & & & \\
\hline & Class IV & 堅穴式梀瓦壁墓 & 複室構造 & & & & & & \\
\hline & Class $\mathrm{V}$ & マスタバ墓 & 複室上部構造，単室下部構造 & & & & & & \\
\hline \multicolumn{4}{|c|}{$\overline{\text { ファイユーム地域 }}$} & & \multicolumn{5}{|c|}{ バダリ地域 } \\
\hline 遺跡 & 類型 & 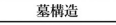 & 借考 & 出典 & 遗䟢 & 類型 & 墓檴造 & 備考 & 出典 \\
\hline \multirow{4}{*}{ セドメント } & Class I & 土塂墓 & 棈円形あるいは矩形 & \multirow{4}{*}{$\begin{array}{c}\text { Petrie } \\
\text { and Brunton } \\
1921\end{array}$} & \multirow{4}{*}{ バダリ地域 } & Class I & 土菜墓 & 腈円形あるいは矩形 & \multirow{4}{*}{$\begin{array}{l}\text { Brunton 1927; 1938; } \\
\text { Bruton and } \\
\text { Caton-Tompson } 1928\end{array}$} \\
\hline & Class II & 壁䉏付属土喏墓 & 矩形で容器を埋納する壁滝をもつ & & & Class II & 竪穴式煤瓦壁墓 & 単室構造 & \\
\hline & Class III & 地下式横穴墓 & 単窒構造 & & & Class UI & 地下式横穴暮 & 单室横造 & \\
\hline & Class IV & 地下式横穴墓 & 複室構造 & & & Class int & 地下项俜入萑 & 单全群追 & \\
\hline & & & & 上エジブト地域 & & & & & \\
\hline 遺跡 & 類型 & 墓構造 & 借考 & 出典 & 遗跡 & 類型 & 墓構造 & 借考 & 出典 \\
\hline \multirow{4}{*}{$\begin{array}{l}\text { ナガ・エド= } \\
\text { デイル }\end{array}$} & Class I & 土境墓 & 棈円形あるいは矩形, 土器棺埋葬1基も含む & \multirow{4}{*}{ Reisner 1908} & \multirow{4}{*}{ エルカブ } & Chass I & 土㙴幕 & 椥円形志るい:矩形 & \multirow{4}{*}{ Hendrickx 1994} \\
\hline & Class II & 堅穴式煉瓦壁墓 & 木製天井張り & & & Class I &  & 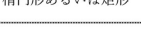 & \\
\hline & Class III & 地下式横穴墓 & $\begin{array}{c}\text { 単室棈造, 埋葬室には戸口が付属するものと } \\
\text { 複室だが規模指数400以下のの }\end{array}$ & & & Class II & 㹂穴式媡瓦壁墓 & 単室構造 & \\
\hline & Class IV & 地下式横穴墓 & $\begin{array}{c}\text { 複室構造，埋葬室に続く階段が付属するものと } \\
\text { 規模指数 } 900 \text { 以上のもの }\end{array}$ & & & Class III & 地下式横穴墓 & 単室構造 & \\
\hline
\end{tabular}




\section{2. 器形・器種の分類}

初期王朝時代の石製容器の分類方法は, エマリーが北サッカラ・大型マスタバ墓群出土石製容器を元 に確立した（Emery 1939；1946）。後にアブ・ロアシュ遺跡で新資料が出土し，バリエーションが増加 したため，エマリーの分類に該当しない器形である GG，II 類などがクラッセンによって追加された (Klasens 1958；1959；1960；1961）。本論では，それら器形分類に基づき対象遺跡の出土資料総計1,193 点を分類した (図 3 )。 $\mathrm{A} ・ \mathrm{~B} ・ \mathrm{C} ・ \mathrm{D}$ 類は円筒形壶, $\mathrm{G} ・ \mathrm{Z}$ 類は無把手壼, $\mathrm{S} ・ \mathrm{~T}$ 類は鉢・皿類である。 これら 3 器種は, 初期王朝時代を通して普遍的に出土し, しばしば共伴して副葬される「基本器種」で ある。本論では, これらの分類に該当しない特徴的な器形で, 且つ出土が非常に少数なものを「特殊器 種」と呼ぶ。ワイン壼や器台, 供物台, 把手付き壷, ビーカー, 盤形容器を始めとして, 口縁部が特徵 的な深鉢や皿などは，特殊器種に該当する。

\section{3. 石製容器の相対的「価値」}

墓は大型になるにつれて埋葬空間も広くなるため, 埋置できる副葬品の数も増える。よって, 副葬点 数以外の指標として, 石製容器の質的側面あるいは相対的な「価值」をここで設定したい。先に掲げた 分類でいう特殊器種は総数 95 点で, 基本 3 器種の総数 1,098 点と比してその出土点数は全体の $10 \%$ に満 たない。この様相は支配者層の墓地である北サッカラ・大型マスタバ墓群でも同様であり，それら特殊 器種には希少価值があった。加えて, 使用石材の相対的価值も設定したい。低位砂漠に産するトラバー チンや石灰岩はアクセスが容易であることから近傍地産石材と言える（図 1)。一方で, 泥岩や玄武岩, 凝灰岩, 閃緑岩, 斑岩は, ファイユーム北部や東部砂漠に採石地があるため, 近傍地産のものより獲得 が困難である。また, 玄武岩や閃緑岩, 斑岩は非常に硬度が高いことから石灰岩やトラバーチンよりも 製作時の作業量は多い。

以上のことから, 特殊器種と遠隔地産石材製のものは, その希少性と獲得時および製作時の労力から 相対的に基本器種や近傍地産石材製よりも高価值であったと仮定できる。これらを前提条件として, 墓 構造からみた社会階層と石製容器の器種組成, 石材構成, 副葬点数を比較することで, 石製容器副葬の 構造を具体化する。

\section{III. 支配者層墓地出土の石製容器について}

まず初めに，当該期の支配者層の集団が埋葬された墓地である北サッカラとウンム・エル＝カアブ出 土の石製容器を概観し, 社会的最上位層における石製容器副葬の組成を把握したい。

（3）エマリーが発掘した北サッカラのマスタバ墓群およびピートリが発掘したウンム・エル＝カアブ出土の石製容 器については, 発掘報告書の中で破片資料を含む全ての資料を掲載しているわけではない。そのため, 両遺跡で定 量的な分析を行うことはできない。また, 第 1 王朝の代表的な遺跡である夕ルカンも扱うことが本来的に望ましい。 しかし, 当該遺跡の発掘報告書および登録カードに掲載されている墓構造は不明瞭であり，加えて石製容器の実測 図が内面まで描かれていない（Petrie 1913）。そのため，エマリーとクラッセンによる器形分類を全資料に対して 照合することが困難であることから，タルカン遺跡は本論の分析から除外した。なお，セドメントに関しては，ピー トリ博物館が無償で提供している墓の登録カードの情報によって発掘報告書の情報を補填・修正している。

（4）使用石材の名称については, 概ね発掘報告書の記載に依拠する。また, 本稿で言及する採石地は, ハレル (Harrel) やブロクサム (Bloxam) らの岩石学的・地質学的調査成果から引用している（Harrel 2013; Harrel et al 2000 ; Bloxam et al 2014)。

（5）石灰岩のモース硬度は2.5, トラバーチン 3〜4, 泥岩 4 5, 玄武岩や閃緑岩, 斑岩はそれぞれ 7 である (Stocks 2003, table 1.1)。ストックス（Stocks）の製作実験では，モース硬度 7 の花崗岩を穿孔するには石灰岩の15 倍もの時間を要するとしている（Stocks 1993）。 
基本器種

1. 円筒形壸 $(A, B, C, D)$
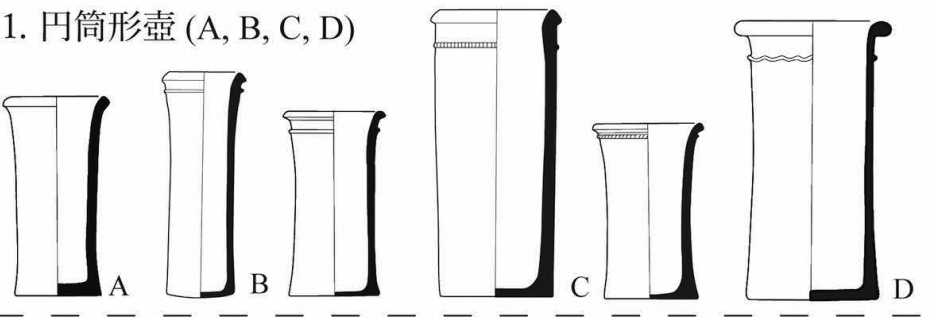

2. 無把手壸 $(\mathrm{G}, \mathrm{Z})$

I

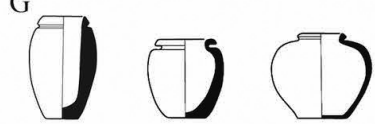

Z
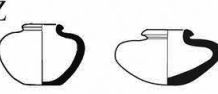

3 . 鉢・皿類 $(\mathrm{S}, \mathrm{T})$

$\mathrm{S}$



$\mathrm{T}$

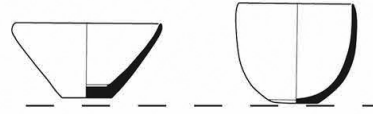

特殊器種
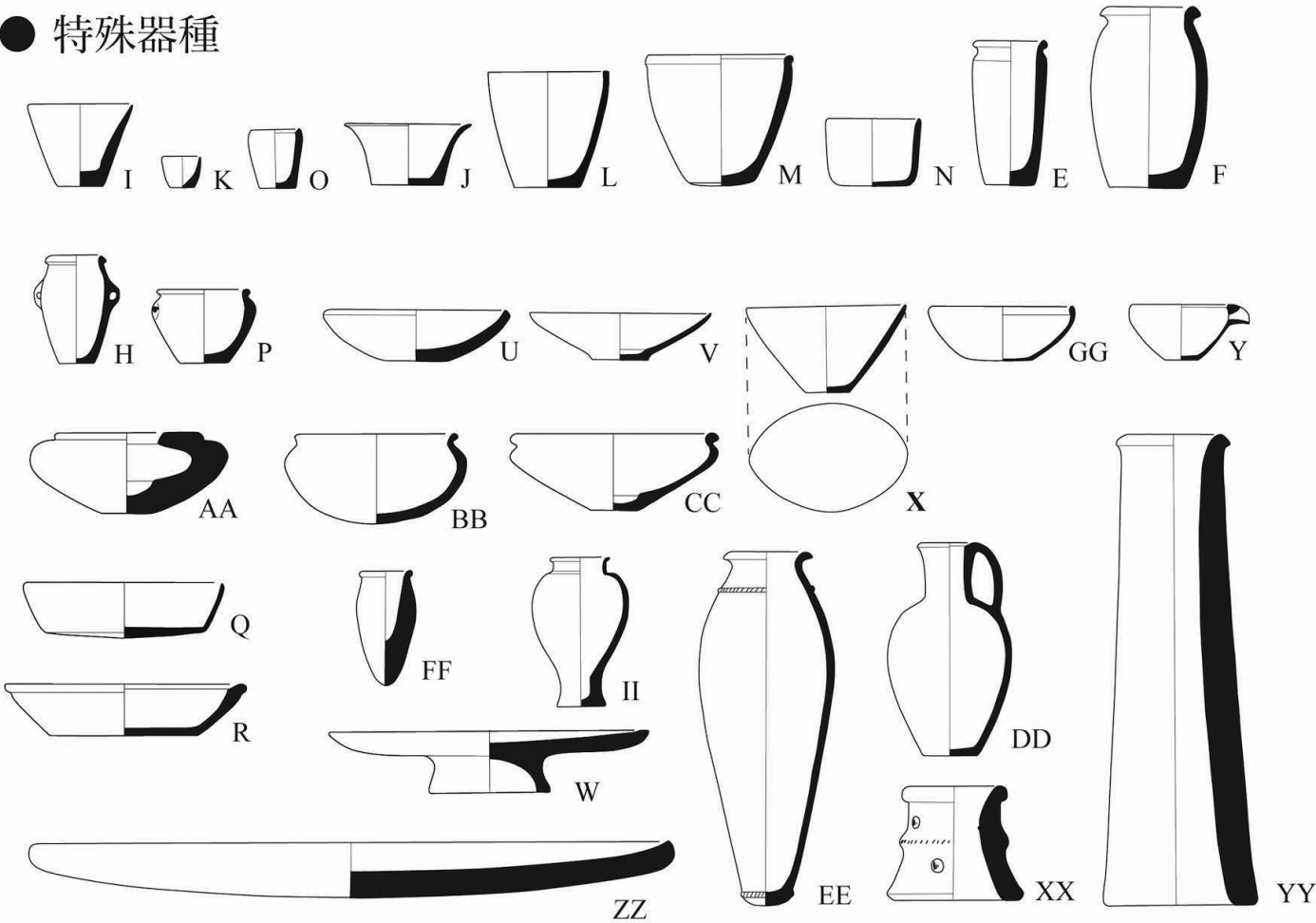

0 $20 \mathrm{~cm}$

・ビーカー形 $(\mathrm{I}, \mathrm{K}, \mathrm{O}) \cdot$ 尖底喆 $(\mathrm{FF})$ ・複数種の鉢, 皿 $(\mathrm{U}, \mathrm{V}, \mathrm{X}, \mathrm{GG}) \cdot$ 注口壹 $(\mathrm{Y})$

- 円筒形壹 $(\mathrm{E}, \mathrm{F}) \cdot$ 深鉢 $(\mathrm{L}, \mathrm{M}, \mathrm{N}) \cdot$ 水盤 $(\mathrm{J}) \cdot$ 胴下部くびれ壱 $(\mathrm{II})$

・複数種の鉢 $(\mathrm{BB}, \mathrm{CC})$ ・盤形容器 $(\mathrm{Q}, \mathrm{R})$ ・ワイン暈 $(\mathrm{EE})$ ・大型無把手壼 $(\mathrm{AA})$

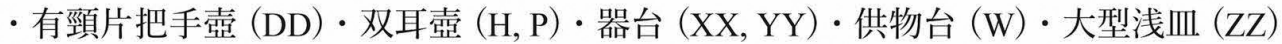

困 3 本稿で扱う遺跡の墓構造分類（Emery 1949, figs. 69A-79; Klasens 1959, figs. 6, 7, 1960, figs. 18, 19; 1961 をもとに作成) 
北サッカラの台地東の縁辺部には，当時の王族あるいは高官たちが埋葬された特別な墓域があり，初 期王朝時代を通じて大型のマスタバ墓が群を成して建造された。当該墓群出土の石製容器は，公表資料 だけで 1 基平均200個体もの副葬点数を数える（Emery 1938；1939；1949；1954; Emery and Klasens 1958)。さらに, 第 1 王朝では, 器種と使用石材の全バリエーションが副葬され, 貯蔵壹（EE 類）や 片把手壶 (DD 類), 器台 (XX, YY 類), 特徵的な口縁部を有する浅鉢（BB， CC 類), 大型の盤形容器 $(\mathrm{Q}, \mathrm{R}$ 類) などの特殊器種は他遺跡では見られない。歴代の王族が埋葬されたウンム・エル＝カアブ でも同様の副葬状況にある（Petrie 1900；1901）。ただし，当該遺跡の資料の大部分が破片且つ未公表 であるためかどうか定かではないが，北サッカラと比して特殊器種の副葬は必ずしも多いわけではない。 とはいえ, 胴部の張り出した円筒形壷 ( $\mathrm{F}$ 類) や大型の双耳喆 ( $\mathrm{H}$ 類), ビーカー ( $\mathrm{I}$ 類), 水盤 ( $\mathrm{J}$ 類), 盤形容器 $(\mathrm{Q}, \mathrm{R}$ 類) といった特殊器種は目立って確認できる。また, 円筒形监はたいていトラバーチ ン製と石灰岩製のものが主体であるが，北サッカラでは玄武岩製や凝灰岩製，ウンム・エル＝カアブで は斑岩製や凝灰岩製，水晶製のもの屯散見される。特に水晶製のものは排他的に両遺跡のみで副葬され る。支配者層の墓地である両遺跡は, 他遺跡と比して石製容器の質・量ともに卓越した様相を呈す。第 2 王朝では，両墓地ともに特殊器種と遠隔地産石材製のものは減少するが，他遺跡と比して突出した組 成の様相に変化はない。

なお，両遺跡では全器種が出土しているにも関わらず，他遺跡で普遍的に見られる無把手彀（G・Z 類）のみが極めて少数であることに留意する必要があるだろう。

\section{IV. 地域分布}

\section{1. 第 1 王朝時代 (表 2)}

メンフィス地域のアブ・ロアシュやザウィエト・エル＝アリヤンでは, 双耳壷（H 類）や注口壼（Y 類), 複数種の皿 (U, V, X, GG 類), 坏 (I 類) といった特殊器種の出土が散見される。供物台（W 類）は北サッカラとアブ・ロアシュでのみ見られる。メンフィス地域以外の地方墓地ではミンシャト・ アブ・オマル, ナガ・エド=デイルに一定数の出土が確認できるものの, メンフィス地域以外は希薄と 言ってよい。同時に, 特殊器種や遠隔地産石材もメンフィス地域に集中している様相にある。出土が少 数の他地方墓地については, テル・エル＝ファルカから 10 点, セドメントから 8 点, バダリ地域抢よび エルカブからそれぞれ 2 点のみ出土している。これらいずれの地域からも特殊器種は 1 ～ 2 点のみで, 遠隔地産石材はない。また, 特殊器種である双耳壷（H 類）は地方 3 遺跡で共通して 1 点ずつ出土し ている。

当該期の石製容器の出土点数や特殊器種, 遠隔地産石材の分布状況はある程度明瞭な中央と地方の二 項対立的な様相を浮き彫りにしている。

\section{2. 第 2 王朝時代 (表 2)}

全体的に特殊器種のバリエーションと凝灰岩以外の遠隔地産石材は減少する。これと連動し, 器種組 成および石材構成は前時期と比してょり定型化する。地方全体で総出土点数101点から329点と大幅に増

（6）ピートリが1899年から1901年にかけて調査したウンム・エル＝カアブにおける王墓（ジェル，デン，メリネイ ト，アジブ，セマルケト，カア，ホル・アハ，ペリブセン，カセケムイ）からは，破片資料含め総計 5 万〜 10 万点 に上る石製容器が出土したようであるが (Petrie 1900, 18), 大多数は未報告である。 
表 2 石製容器の地域分布（上：第 1 王朝時代, 下：第 2 王朝時代）

\begin{tabular}{|c|c|c|c|c|c|c|c|c|c|c|c|c|c|c|c|c|c|c|c|c|c|}
\hline \multirow{2}{*}{ 地域区分 } & \multirow{2}{*}{ 遺跡 } & \multicolumn{4}{|c|}{ 基本器種 } & \multicolumn{14}{|c|}{ 特殊器種 } & \multirow{2}{*}{\multicolumn{2}{|c|}{ 合計 遠隔地産石材 }} \\
\hline & & A, B, C, D & G, $\mathbf{Z}$ & $\mathrm{S}, \mathrm{T}$ & W & I & $\mathbf{K}$ & $\mathbf{L}$ & $\mathbf{U}$ & $\mathbf{H}$ & $\mathbf{J}$ & $\mathbf{Y}$ & $\mathbf{V}$ & $\mathbf{X}$ & M & $\mathbf{E}$ & II & BB & DD & & \\
\hline \multirow{2}{*}{$\begin{array}{c}\text { 東部デルタ } \\
\text { 地域 }\end{array}$} & ミンシャト・アブ・オマル & 7 & 11 & 14 & - & - & - & 1 & - & - & - & - & - & - & - & - & 1 & - & - & 34 & - \\
\hline & テル・エル $=$ ファルカ & 3 & 1 & 4 & - & - & - & - & - & 1 & - & - & 1 & - & - & - & - & - & - & 10 & 5 \\
\hline \multirow{4}{*}{$\begin{array}{c}\text { メンフィス } \\
\text { 地域 }\end{array}$} & アブ・ロアシュ & 42 & 23 & 101 & 5 & 1 & 1 & - & 2 & 2 & - & 1 & 1 & 1 & 1 & - & - & - & - & 181 & 49 \\
\hline & ヘルワン & & & & & & & & & & & & & & & & & & & \multicolumn{2}{|c|}{${ }_{1}=1$} \\
\hline & ザウィエト・エル＝アリヤン & 10 & 1 & 14 & - & 1 & 3 & 2 & 4 & 5 & - & - & 1 & - & - & - & - & - & - & 41 & 13 \\
\hline & タルカン & 120 & 86 & 101 & - & 1 & 3 & 1 & - & 5 & - & 2 & 3 & - & - & - & 2 & - & - & 324 & 14 \\
\hline $\begin{array}{c}\text { ファイユーム } \\
\text { 地域 }\end{array}$ & セドメント & 1 & 6 & 1 & - & - & - & - & - & - & - & - & - & - & - & - & - & - & - & 8 & - \\
\hline $\begin{array}{c}\text { 中部エジプト } \\
\text { 地域 }\end{array}$ & バダリ地域 & - & - & 1 & - & - & - & - & - & 1 & - & - & - & - & - & - & - & - & - & 2 & - \\
\hline 上エジプト & ナガ・エド =デイル & 12 & 5 & 27 & - & - & - & - & - & - & - & - & 1 & - & - & - & - & - & - & 45 & 15 \\
\hline 地域 & エルカブ & 1 & - & - & - & - & - & - & - & 1 & - & - & - & - & - & - & - & - & - & 2 & - \\
\hline
\end{tabular}

\begin{tabular}{|c|c|c|c|c|c|c|c|c|c|c|c|c|c|c|c|c|c|c|c|c|c|}
\hline \multirow{2}{*}{ 地域区分 } & \multirow{2}{*}{ 遺跡 } & \multicolumn{4}{|c|}{ 基本器種 } & \multicolumn{14}{|c|}{ 特殊器種 } & \multirow{2}{*}{\multicolumn{2}{|c|}{ 合計 遠隔地産石材 }} \\
\hline & & A, B, C, D & G, Z & $\mathbf{S}, \mathbf{T}$ & W & $\mathbf{I}$ & $\mathbf{K}$ & $\mathbf{L}$ & $\mathbf{U}$ & H & $\mathbf{J}$ & $\mathbf{Y}$ & $\mathbf{V}$ & $\mathbf{X}$ & $\mathbf{M}$ & $\mathbf{E}$ & II & BB & DD & & \\
\hline \multirow{2}{*}{$\begin{array}{c}\text { 東部デルタ } \\
\text { 地域 }\end{array}$} & ミンシャト・アブ・オマル & & 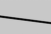 & & & & & & & & & & & & & & & & & & \\
\hline & テル・エル $=$ ファルカ & 5 & 35 & 4 & - & - & - & - & 1 & - & - & - & 1 & - & - & - & 1 & - & - & 47 & 5 \\
\hline \multirow{4}{*}{$\begin{array}{c}\text { メンフィス } \\
\text { 地域 }\end{array}$} & アブ・ロアシュ & 38 & 113 & 124 & 12 & 2 & - & 6 & 2 & - & 1 & - & - & - & - & - & - & - & - & 298 & 13 \\
\hline & ヘルワン & 80 & 11 & 141 & 3 & - & 1 & - & 3 & - & - & - & - & - & - & - & - & - & 2 & 241 & 22 \\
\hline & ザウィエト・エル＝アリヤン & &  & & & & & & & & & & & & & & & & & \multicolumn{2}{|c|}{$N^{2}$} \\
\hline & タルカン & & & & & & & & & & & & & & & & & & & \multicolumn{2}{|c|}{ 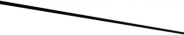 } \\
\hline $\begin{array}{c}\text { ファイユーム } \\
\text { 地域 }\end{array}$ & セドメント & 5 & 10 & 13 & 6 & - & 2 & - & - & 1 & - & - & - & - & 1 & - & - & 1 & - & 39 & 3 \\
\hline $\begin{array}{c}\text { 中部エジプト } \\
\text { 地域 }\end{array}$ & バダリ地域 & 3 & 18 & 10 & 2 & - & 2 & 2 & - & 1 & - & - & - & - & - & - & - & 2 & - & 40 & 2 \\
\hline \multirow{2}{*}{$\begin{array}{c}\text { 上エジプト } \\
\text { 地域 }\end{array}$} & ナガ・エド=デイル & 41 & 24 & 106 & - & - & - & - & - & - & - & 4 & 1 & 2 & 1 & 2 & - & - & - & 181 & 61 \\
\hline & エルカブ & 1 & 14 & 6 & 2 & - & - & - & - & - & - & - & - & - & - & - & - & - & - & 22 & - \\
\hline
\end{tabular}

加し, 特殊器種と遠隔地産石材も全遺跡で確認できる。とくに, 平面が楕円形を呈する鉢類（X類）や 張り出した底部をもつ皿類 ( $\mathrm{V}$ 類), 注口喆 $(\mathrm{Y}$ 類), 口唇部が水平の深鉢類（ $\mathrm{L}$ 類）が多い。へルワン で見られる水差し（DD 類），セドメントおよびバダリ地域の BB 類，ナガ・エド＝デイルの $\mathrm{E}$ 類は， 第 1 王朝では北サッカラでのみ副葬される特殊器種である。さらに特記すべきは, 第 1 王朝にザウィエ ト・エル＝アリヤンとタルカンで限定されていた供物台がこの時期に, 点数上は未だ基本器種には達し ないものの，2遺跡を除く全遺跡で確認できることである。

ミンシャト・アブ・オマルはこの時期に廃絶するが，同地域のテル・エル＝ファルカでは75点の石製 容器が出土する。セドメントとバダリ地域, エルカブでも急増する様相を呈す。中でも, ナガ・エド= デイルでは副葬される墓数と副葬点数が飛躍的に増加し，地方墓地としては異質な様相にある。墓構造 もメンフィス地域の最上位層と遜色なく, 大型の墓が多数営まれ，特殊器種や遠隔地産石材も豊富に副 葬される。

\section{V. 階層秩序と石製容器の副葬状況}

\section{1. 第 1 王朝時代 (表 3 )}

メンフィス地域のアブ・ロアシュ遺跡では，特殊器種と遠隔地産石材が最上位層 Class IV の墓に限 定されていたことが明瞭であり, 副葬点数む上位になるにしたがい増加傾向にある。最下層の Class I は円筒形壹と鉢・皿類のみでそれぞれ 1 個体しか副葬されない。当該遺跡では，器種組成と石材構成が 


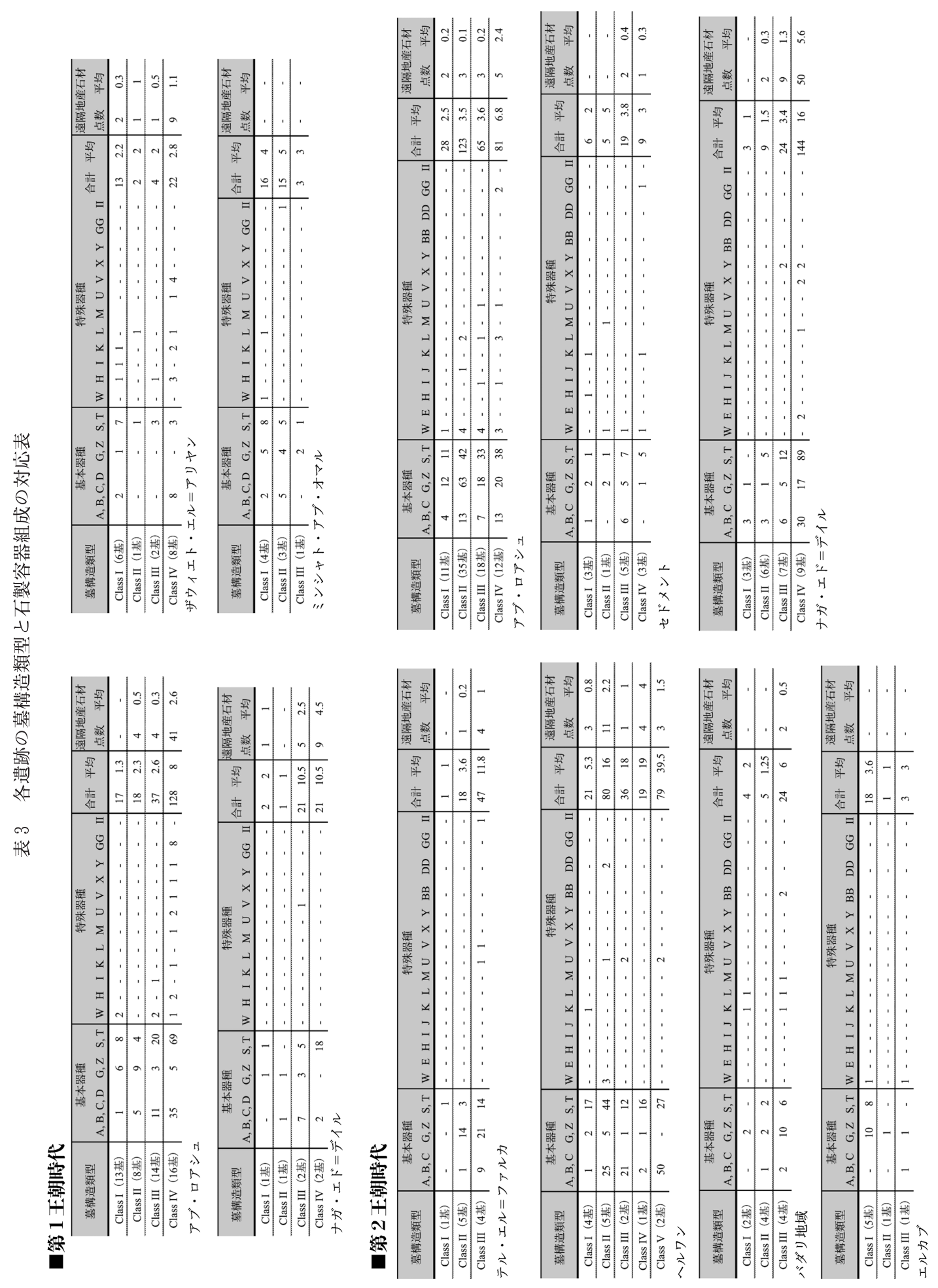


階層秩序の勾配に沿って副葬された。ザウィエト・エル＝アリヤンでは Class I に特殊器種の副葬が若 干見られるものの, やはり最上位層 Class III の墓に多数の特殊器種が集中し種類も豊富である。同じ くClass III には遠隔地産石材も集中し, 副葬点数も他の墓構造を上回っている。メンフィス地域では, 北サッカラに扔ける支配者層の墓を頂点として, 概ね上位層の墓に特殊器種と遠隔地産石材が副葬され る傾向が強い。また, 北サッカラの大型マスタバ墓群では無把手壶が極めて少数である。無把手壶の少 数さは，アブ・ロアシュやザウィエト・エル＝アリヤン，ナガ・エド=デイルの上位層の墓でも同様で あった。

一方で, 地方墓地の中では出土点数の多いミンシャト・アブ・オマルでは, 石製容器の器種組成や副 葬点数といった各属性と墓構造・規模との相関性は全く認められない。ナガ・エド=デイルにおいては 遠隔地産石材が最上位層 Class IV に副葬される傾向が強いが, メンフィス地域のような石製容器の階 層秩序を地方墓地で想定することはできない。そもそも両遺跡はいずれも特殊器種が極めて少数である。 5 基から 10 点出土しているテル・エル＝ファルカでも, 単純な土壙墓と竪穴墓あるいは墓壙規模間で器 種組成・使用石材・副葬点数に差異はない。

\section{2. 第 2 王朝時代 (表 3 )}

メンフィス地域のアブ・ロアシュでは引き続き副葬点数と特殊器種, 遠隔地産石材は上位層になるに したがい増加する傾向にある。ヘルワンでは, 特殊器種の多夏は必ずしも階層性とは一致しないものの, 遠隔地産石材と副葬点数においては相関性が確認できる。第 1 王朝に北サッカラにしか副葬されなかっ た水差し（DD 類）は，この時期へルワン遺跡にも器高 $3 \mathrm{~cm}$ 前後のミニチュアとして現れるが, Class II の墓に副葬された。テル・エル＝ファルカやバダリ地域, ナガ・エド=デイルといった地方墓地では, 特殊器種と遠隔地産石材が排他的に最上位層の墓群に副葬されるようになり, 前時期のメンフィス地域 と同じ様相にあることがわかる。一方で，セドメントでは特殊器種と遠隔地産石材は階層に相関なく副 葬され，それらに偏在性はない。エルカブでは基本 3 器種と供物台，近傍産石材のみからなる。

無把手壶はこの時期になってむメンフィス地域，特にヘルワンの上位層の墓には少ない。北サッカラ の大型マスタバ墓群とウンム・エル＝カアブでも同様である（Petrie 1901; Emery 1949）。とはいえ， 無把手壼の増加に伴って, アブ・ロアシュやそれ以外の地方では, 普遍的に上位層の墓からも出土する。 また，下位層 Class I の墓には円筒形壼が副葬されない場合が多い。第 1 王朝のナガ・エド＝デイルや 第 2 王朝のテル・エル＝ファルカ，バダリ地域，エルカブはそれに該当する。

\section{VI. 考察一石製容器副葬の階層構造と社会的機能一}

第 1 王朝時代, 石製容器の分布状況から石製容器の副葬が一般的であったのは首都圈であるメンフィ ス地域とウンム・エル＝カアブの王墓地にほぼ限定されていた。少数ながら地方墓地でも石製容器の副 葬は確認できるものの, 器種組成と石材構成が階層秩序と一定に共変動する様相はメンフィス地域にの み認められる。「高価值」な器種・石材は上位層の集団・地域との結びつきが強く，それらは当時の集 団・地域間の支配権力関係に対応する形で副葬されたと想定できる（図 4 ）。少なくともメンフィス地 域以外の地方に恒常的・安定的な生産組織はなかったであろうし（竹野内 2016）, あるいは目的立って 製品が流通していたわけでもないだろう。つまり, 当該期には, メンフィス地域とウンム・エル＝カア ブ双方のみにおいて石製容器の集約的な生産と副葬が見られる。社会経済的格差や支配権力の地理的範 


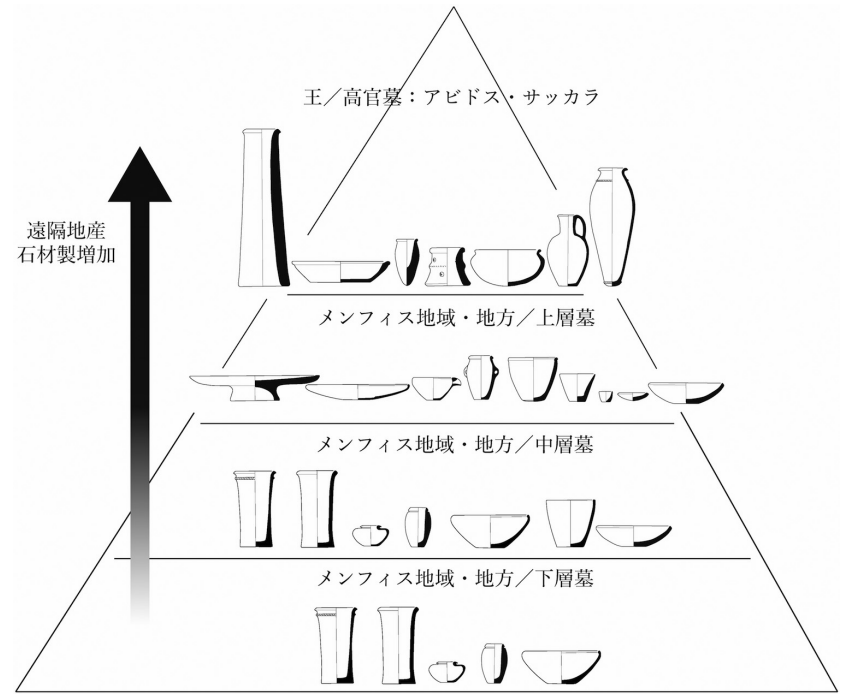

図 4 石製容器副葬の階層構造概念図

囲に応じて石製容器は利用されていた と考えられる。また，メンフィス地域 において，無把手壷は上位層になるに したがい副葬が希薄であった。無把手 壷の価值が相対的に低かったことが窥 われる。

メンフィス地域に集中する様相は続 く第 2 王朝時代に転換する。当該期に 地方墓地でも石製容器の副葬が大幅に 増加し, 並行してさらなる大量生産化 を指向する製作上の技術選択が図られ る (Hendrickx et al. 2001; 竹野内 2016)。同時に, 地方墓地でも特殊器 種と遠隔地産石材に基づく副葬の階層 構造を倣う。メンフィス地域で遵守された副葬原理が中央統制下で地方にまで浸透したようである。一 方で, この時期でも北サッカラとウンム・エル＝カアブに加え，無把手壼が最上位層の墓で希薄な遺跡 は王族クラスも埋葬されたヘルワンのみである。そう考えると，無把手壸は初期王朝を通じて社会的に 極めて高位な集団には敬遠されていた可能性が高い。また，カウ遺跡3112号墓出土鉢形容器の破片の外 面には，王銘（ヘテプ・セケムウイ Hetep Sekemui）が刻印されている（Brunton 1927, 17-18, pl. XIX, no. 25)。おそらく贈与品であったことが窥われよう。このことから，バダリ地域はおそらく搬入品に依存 していた。セドメント314号墓でもセレクが刻まれた円筒形喆が出土している（Petrie and Brunton 1921， pl. III, no. 31)。遺跡間の容器サイズや石材構成の傾向からも地方墓地に副葬された石製容器は基本的に 流通品であり，地方には固有の生産組織はなかったと考えられる（竹野内 2016）。刻印された王銘や容 器サイズの様子を見る限り, 第 2 王朝には少なくとも一部の良品は地方へ配布されたのだろゔ。セドメ ントとバダリ地域では北サッカラでしか見られない BB 類が副葬されたことも, 配布による結果と考え るのが妥当であろう。だとすれば，中央から地方豪族へ石製容器を配布する，あるいは階層構造が規範 として浸透する必要性やその背景はどこにあったのか。

地方豪族との婚姻関係や王とその側近によるエジプト全土の行脚の必要性 (Wilkinson 2010), 地方 神殿の自立性（Bussmann 2011）は, 初期王朝時代が国家社会であれ，未だ中央の求心性と地方の統制 が脆弱な社会であったことを示す。そのため, 中央と地方の贈与あるいは下賜関係による協同性の確保 が必要となり, 同じ価值体系や倫理規範の広域的共有が石製容器という物質的媒体を用いることで促進 された可能性がある。メンフィス政権の支配者層は, デル夕地域やバダリ地域以南の地方豪族へ向けて 石製容器を配布していたことが想定される。そうした配布に加え, 婚姻関係の締結や徴税のための行脚 は，地方における規範概念の認識・是認へと繋がる。器種の選択と副葬を一つの「儀礼」的行為と捉え

（7） テル・エル＝ファルカ遺跡では，石製容器の工房址が検出されている (Chłodnicki et al 2012)。容器サイズの 傾向からも, 当該遺跡出土の石製容器は基本的に在地生産品であると考えられる（竹野内 2016）。そのため, 配布 ではなくとも, 石製容器副葬の階層構造は指向されていたことが想定される。

（8）代表的な例では, 第 1 王朝時代のナルメル王がナカダ地域の豪族の娘であるネイトへテプと婚姻関係を結び, 上エジプト地域との同盟関係を強めた（Wilkinson 1999, 71）。 
るのであれば,こうしたイデオロギー的・象徴的位相の共同性は, 集団間・地域間の結びつきを強め, 帰属意識を高める（Kertzer 1988; DeMarris et al. 1996; Lucero 2003）。第 1 王朝時代の階層規範は首都 圈であるメンフィス地域内部で生成され且つ社会的上位層を中心としたものであったがゆえに，第 2 王 朝時代に扔ける葬送イデオロギー普及の実効性と石製容器それ自体が帯びた社会的権力の物質性や象徵 性を裏付けた（Walker and Schiffer 2006）。

メンフィス地域の中心政権は各地の地方豪族へ石製容器を配布したり, 徵税のための行脚を実施する ことによって政治的・イデオロギー的紐帯を結んだ。無論，石製容器の配布は紐帯強化を目論んだ支配 者側の行為全体の中の一つに過ぎなかったと評価すべきである。政治権力や経済基盤を形成・向上させ るための様々な戦略があったはずである（Lucero 2003, 524）。いずれにせよ, 共通「儀礼」の遵守は政 体範囲を定め, 前よりも大規模な範囲で政治的に組織する際の手段であることから (Kertzer 1988, 19), これらは地域統合を企図した動きであったことがわかる。

一方で, セドメントでは石製容器副葬の階層性が明瞭でない。上位層の墓構造の中でも, 全てが共通 して特殊器種と遠隔地産石材を持ち得るわけでもない。地域個別の文脈や自立的な葬送文化の様式も考 える必要があろう。そのため, 以上のような石製容器の副葬原理は, むとより厳密な約束事とは見做し 難く, 特殊器種と遠隔地産石材の経済的価值に基づく「緩慢な優先順位・遵守事項」がグラデーション を成すように発露したと考えた方がよさそうである。

\section{VII. 結論と課題}

第 1 王朝においてメンフィス地域首都圈内で紐帯意識を維持・強化すべく, 石製容器の特殊器種と遠 隔地産石材に基づく副葬の「緩慢な」階層原理が生まれた。第 2 王朝になると，他地域とより強固な紐 帯を結ぶために, 石製容器の配布などを介して地域統合を企図したと考えられる。石製容器は集団間・ 地域間を取り結ぶための戦略的・象徽的な権力資源として，まさに支配者層によって選好され，動員さ れた器物であったと結論づけたい。石製容器の大量生産化の背景の一つには，こうした支配者層の動向 を挙げることができる。

以前拙稿において流通・消費される石製容器のサイズの大小や石材構成が地域的な階層性に沿って決 定されていたことを述べた（竹野内 2016）。階層秩序に基づく石製容器の流通や副葬は，バル夕が指摘 するように，ナイル川下流域統一後の社会階層が発達した第 1 王朝時代から, 宗教の中心主題が個人の 社会的地位に基づく「来世へのアクセス性の度合い」になったことを反映している（Bárta 2011, 48）。 前述した通り，初期王朝社会は国家としては萌芽段階であり，エジプト全土を厳格に管理統制できるほ どの成熟した行政機構・官僚制度を有していなかった。古王国時代のようにピラミッド複合体が可視的 な象徴資本として権力の維持・再生産を担うわけでもない。そうした状況において，石製容器などの 「威信財」を権力基盤とする社会秩序の創出が一つの政治戦略であったと考えても大きな齟䶜はあるま い(Friedman and Rowlands 1977)。

（9）フリードマンやローランズが提唱したような威信財システムの構造を念頭に置くと理解しやすい（Friedman and Rowlands 1977)。中央で生産された石製容器は地方豪族へ配布され，豪族はさらに自らの配下へ配る。社会的 地位や階層のフィルターに濾された石製容器は徐々に器種・石材が安価なものになり, 結果としてピラミッド型の 副葬原理になった可能性がある。初期王朝時代では，石製容器の他に織物や青銅製品などが挙げられる。擬制的な リネージ関係を形成・維持するために, こうした「威信財」と呼称できる物品の生産と配布が有効と考えられてい る。 
一方で，いわゆる垂直的な階層関係だけで一元的にその副葬が決定されていたと考えるのは早計であ ろう。本稿ではあくまで集団間関係の一つである「墓建造への投下労働量からみた社会的地位や階層性」 を共変動にして分析を行った。副葬原理の一つとして確実に社会の垂直性が関わっており, 特殊器種や 遠隔地産石材といった経済的な価值が高いものほど社会的地位の高い集団がアクセスできるのは当然で ある。しかし，例えば埋葬儀礼における容器選択の多様性があったとすれば，個々人の嗜好性や水平的 な組織（職業区分や出自の差異），個人間・集団間の信仰体系など副葬品の選択性に関する決定因子は 様々に予想される。もとより, 石製容器の副葬状況は一つの副葬原理によって貫かれた単配列的な構造 ではなく, 複数の要素・因子が共有され且つそのどれもが十分／必要条件にならない「多配列的構造」 として見做すべきかもしれない（Needham 1975）。そのためには，他の共変動する属性とのパターンの 模索や同時代のスラブステラおよび古王国時代の供物リストとの照合も急務であろう。また，第 3 王朝 のジェセルの階段ピラミッドの地下貯蔵庫からは優に 4 万点を超える第 2 王朝に製作された石製容器が 出土している（Firth and Quibel 1935）。本稿の対象資料を遙かに陵駕する点数であるため，ここでの結 論は当時の石製容器生産を捉えきったものではないことを明記する。

さらに土器や銅製容器といった他の容器との関係性は看過できない。単純に土器の上位互換として石 製容器を認識することには多いに疑問符が付く。この時期の土器は基本的に貯蔵用の器形であり，坏や 鉢，皿といった供食用容器は少ない。比して石製容器はむしろ鉢や血が副葬の大多数を占める。また， この時期の銅製容器は注口壼と水盤のセットからなり，いわゆる清めの儀礼に用いられた容器である。 こうした葬送上の容器の機能的な差異に関する何らかのパターンがそれらの組み合わせ上で見出されて もおかしくない。こうした土器や銅製容器を含めた容器副葬の解明も課題の一つに挙げ，本稿を閉じる こととする。

\section{謝辞}

本稿は, 日本オリエント学会第57回大会にて口頭発表した「エジプト原・初期王朝時代における石製容器の階層規 範」および $5^{\text {th }}$ International Congress for Young Egyptologistsにて口頭発表した “The Change of Funerary Culture and Stone Vessel Production in Early State”, 第21回日本西アジア考古学会総会・大会にて口頭発表した「エジプト初期 王朝時代における石製容器の地域的保有状況と流通網の変化」の成果に基づき大幅に修正を加えたものである。本論 を執筆するにあたって, 近畿大学の高宮いづみ教授や早稲田大学高等研究所の馬場匡浩准教授にはご助言を睗りまし た。また，査読者の方々には有益なご指摘を頂きました。末筆ではありますが感謝申し上げます。

なお，本稿は平成28年度研究活動スタート支援（課題番号：16H07272）を受けて行われた研究成果の一部である。

\section{参照文献}

Aston, B. G. 1994: Ancient Egyptian Stone Vessels: Materials and Forms, Heidelberg: Heidelberger Orientverag.

Bard, K. 1988: “A Quantitative Analysis of the Predynastic Burials in Armant Cemetery 1400-1500," The Journal of Egyptian Archaeology 74, 39-55.

Bárta, M. 2011: Journey to the West: The World of the Old Kingdom Tombs in Ancient Egypt, Prague: Charles University in Prague.

Binford, L. R. 1971: "Mortuary Practices: Their Study and Their Potential," Memories of the Society for American Archaeology 25, 6-29.

Brown, J. A. 1981: "The Search for Rank in Prehistoric Burials," in R. Chapman et al. (eds.), The Archaeology of Death, Cambridge: Cambridge University Press, 25-37.

Brunton, G. 1927: Qau and Badari, I, London: British School of Archaeology in Egypt.

Brunton, G. 1938: Matmar, London: British School of Archaeology in Egypt. 
Brunton, G and G. Caton-Tompson 1928: The Badarian Civilisation and Predynastic Remains near Badari, London: British School of Archaeology in Egypt.

Bussmann, R. 2011: "Local Traditions in Early Dynastic Temples,” in R. F. Friedman and P. N. Fiske (eds.), Egypt at Its Origins, 3, Leuven: Peters, 747-762.

Carr, C. 1995: "Mortuary Practices: Their Social, Philosophical-Religious, Circumstantial, and Physical Determinants," Journal of Archaeological Method and Theory 2/2, 105-200.

Chłodnicki, M. et al. 2012: Tell El Farkha, I, Excavations 1998-2011, Poznan and Krakow: Poznan Archaeological Museum and Institute of Archaeology, Jagiellonian University.

DeMarris, E. et al. 1996: "Ideology, Materialization, and Power Strategies," Current Anthropology 37/1, 15-31.

Dunham, D. 1978: Zawiyet El-Aryan, Boston: Museum of Fine Arts, Boston.

Ellis, C. 1992: "A Statistical Analysis of the Protodynastic Burials in the "Valley” Cemetery of Kafr Tarkhan,” in E. C. M. van den Brink (ed.), The Nile Delta in Transition: $4^{\text {th }}-3^{\text {rd }}$ Millennium BC, Tel Aviv: Israel Exploration Society.

Emery, W. B. 1938: Excavation at Saqqara: The Tomb of Hemaka, Cairo: Egypt Exploration Society.

Emery, W. B. 1939: Excavation at Saqqara 1937-1938: Hor-Aha, Cairo: Egypt Exploration Society.

Emery, W. B. 1949: Great Tombs of the First Dynasty, Pt. I, Cairo: Egypt Exploration Society.

Emery, W. B. 1954: Great Tombs of the First Dynasty, Pt. II, London: Egypt Exploration Society.

Emery, W. B. and A. Klasens 1958: Great Tombs of the First Dynasty, Pt. III, London: Egypt Exploration Society.

Engel, E.-M. 2013: “The Organization of a Nascent State: Egypt until the Beginning of the $4^{\text {th }}$ Dynasty,” in J. C. M. Garcia (ed.), Ancient Egyptian Administration, Leiden and Boston: Brill.

Firth, C. M and J. E. Quibel 1935: Excavations at Saqqara: The Step Pyramid, Cairo: Institut Français d'Archéologie Orientale.

Friedman, J. and M. J. Rowlands 1977: “Notes towards an Epigenetic Model of the Evolution of 'Civilisation', in J. Friedman and M. J. Rowlands (eds.), The Evolution of Social Systems, London: Duckworth, 201-276.

Griswold, W. A. 1992: "Measuring Social Inequality at Armant," in R. Friedman and B. Adams (eds.), The Followers of Horus, Oxford: Oxbow, 193-198.

Harrel, J. A. 2013: “Ornamental Stones," UCLA Encyclopedia of Egyptology, UC Los Angeles (http://uee.ucla.edu/; accessed on 28 November 2016).

Harrel, J. A. et al. 2000: “An Early Dynastic Quarry for Stone Vessels at Gebel el Manzal el-Seyl, Eastern Desert,” The Journal of Egyptian Archaeology 86, 33-42.

Hendrickx, S. 1994: Elkab, V, The Naqada III Cemetery, Brussels : Royal Museum of Art and History.

Hendrickx, S. 2006: "Predynastic-Early Dynastic Chronology," in E. Hornang et al. (eds.), Ancient Egyptian Chronology, Leiden and Boston: Brill.

Hendrickx, S. 2011: “Crafts and Craft Specialization," in E. Teeter (ed.), Before the Pyramids: The Origins of Egyptian Civilization, Chicago: Oriental Institute Museum Publications, 93-98.

Hendrickx, S. 2014: "The Emergence of the Egyptian State," in C. Renfrew and P. Bahn (eds.), The Cambridge World Prehistory, vol. 1, Cambridge: Cambridge University Press, 259-278.

Hendrickxs, S. et al. 2001: "Excavating in the Museum: The Stone Vessel Fragments from the Royal Tombs at Umm elQaab in the Egyptian Collection of the Royal Museums for Art and History at Brussels," Mitteilungen des Deutschen Archäologischen Instituts, Abteilung Kairo 57, 73-108.

Jórdeczka, M. 2004: "Stone Implements from Tell El-Farkha," in S. Hendrickxs et al. (eds.), Egypt at Its Origin, Leuven and Dudley, Mass.: Peeters, 443-463.

Kemp, B. J. 2000: "The Colossi from the Early Shrine at Coptos in Egypt,” Cambridge Archaeological Journal 10, $211-242$. Kertzer, D. I. 1988: Ritual, Politics, and Power, New Haven: Yale University Press.

Klasens, A. 1958: “The Excavation of the Leiden Museum of Antiquities at Abu Roash: Report of the First Season: 1958. Pt. I," Oudheidkundige Mededelingen uit het Rijksmuseum van Oudheden te Leiden 39, 32-55.

Klasens, A. 1959: "The Excavation of the Leiden Museum of Antiquities at Abu Roash: Report of the First Season: 1958. 
Pt. II: Cemetery 400," Oudheidkundige Mededelingen uit het Rijksmuseum van Oudheden te Leiden 40, 41-61.

Klasens, A. 1960: "The Excavation of the Leiden Museum of Antiquities at Abu Roash: Report of the First Season: 1959.

Pt. I," Oudheidkundige Mededelingen uit het Rijksmuseum van Oudheden te Leiden 41, 69-94.

Klasens, A. 1961: "The Excavation of the Leiden Museum of Antiquities at Abu Roash: Report of the First Season: 1959.

Pt. II," Oudheidkundige Mededelingen uit het Rijksmuseum van Oudheden te Leiden 42, 108-128.

Köhler, C. E. 2008: "Early Dynastic Society at Memphis," in E.-M. Engel et al. (eds.), Zeichen aus dem Sand: Streiflichter aus Ägyptens Geschichte zu Ehren von Günter Dreyer, Wiesbaden: Harrassowitz Verlag, 381-399.

Köhler, C. E. 2014: Helwan, III, Excavations in Operation 4, Tombs 1-50, Rahden: Vml Verlag Marie Leidorf.

Kopp, P. 2007: "Prä- und frühdynastische Steingefässe: Chronologie und soziale Divergenz,” Mitteilungen des Deutschen Archäologischen Instituts, Abteilung Kairo 63, 193-210.

Kouli, A. 1978: Egyptian Stone Vessels: Predynastic Period to Dynasty III: Typology and Analysis, Mazin: von Zabern.

Kroeper, K. von and D. Wildung 1994: Minshat Abu Omar, I, Ein vor und frühgeschichtlicher Friedhof im Nildelta, Gräber 1-114, Mainz: Verlag Phillip von Zabern in Wissenschaftliche Buchgesellschaft.

Kroeper, K. von and D. Wildung 2000: "Minshat Abu Omar, II, Ein vor und frühgeschichtlicher Friedohof im Nildelta, Gräber 115-204," Mainz: Verlag Phillip von Zabern in Wissenschaftliche Buchgesellschaft.

Lucero, L. J. 2003: “The Politics of Ritual: The Emergence of Classic Maya Rulers,” Current Anthropology 44/4, 523-558. Mallory, L. M. 2000: "Predynastic and First Dynasty Egyptian Basalt Vessels," Ph. D. dissertation, University of Toronto. Needham, R. 1975: "Polythetic Classification: Convergence and Consequences," Man (N. S.) 10/3, 349-369.

Petrie, W. M. F. 1900: The Royal Tombs of the Earliest Dynasties, Pt. I, London: The Egypt Exploration Society.

Petrie, W. M. F. 1901: The Royal Tombs of the Earliest Dynasties, Pt. II, London: The Egypt Exploration Society.

Petrie, W. M. F. 1913: Tarkhan I and Memphis V, London: British School of Archaeology in Egypt.

Petrie, W. M. F. and G. Brunton 1921: Sedment I, London: British School of Archaeology in Egypt.

Raffaele, F. 2005: “Stone Vessels in Early Dynastic Egypt,” Cahiers Caribéens d'Egyptologie 7-8, 47-60.

Reisner, G. A. 1908: The Early Dynastic Cemeteries of Naga-Ed-Der, Pt. 1, Leipzig: J. C. Hinrichs.

Schmidt, K. 1988: “Die lithischen Kleinfunde, Tell el Fara'in-Buto, 3. Bericht,” Mitteilungen des Deutschen Archäologischen Instituts, Abteilung Kairo 44, 297-306.

Stocks, D. A. 1993: "Making Stone Vessels in Ancient Mesopotamia and Egypt," Antiquity 67/356, 596-603.

Stocks, D. A. 2003 : Experiments in Egyptian Archaeology: Stoneworking Technology in Ancient Egypt, London and New York: Routledge.

Reisner, G. A. 1936: The Development of the Egyptian Tomb down to the Accession of Cheops, Cambridge, Mass.: Harvard University Press.

Tainter, J. A. 1978: "Mortuary Practices and the Study of Prehistoric Social Systems," in M. Schiffer (ed.), Advances in Archaeological Method and Theory, 1, New York: Academic Press, 23-33.

Walker, W. H. and M. B. Schiffer 2006: “The Materiality of Social Power: The Artifact-Acquisition Perspective,” Journal of Archaeological Method and Theory 13/2, 67-88.

Wetering, J. von and J. Tassie 2003: "Socio-Political Hierarchy of First Dynasty Sites: A Ranking of East Delta Cemeteries Based on Grave Architecture,” in A. K. Eyma and C. J. Bennett (eds.), A Delta-Man in Yebu, Boca Raton: Universal Publishers.

Wilkinson, T. 2010: “The Early Dynastic Period,” in A. B. Loyd (ed.), A Companion to Ancient Egypt, vol. 1, Oxford: WileyBlackwell, 48-62.

竹野内恵太 2015 ：「エジプト先・初期王朝時代における石製容器の穿孔・研磨技術序論」『早稲田大学文学研究科紀 要』60, 83-99.

竹野内恵太 2016 ：「エジプト初期王朝時代における石製容器の生産・流通メカニズム：容器サイズの分析を中心に」 『西アジア考古学』17, 117-136.

張替いづみ 1991 :「エジプト・ナカダ文化における象牙製品について」滝口宏『古代探叢III：早稲田大学考古学会 創立40周年記念考古学論集』, 早稲田大学出版部, 635-650. 